\title{
Epidural administered buprenorphine in the perioperative period
}

Yasuko Miwa MD, Eiji Yonemura MD, Kazuaki Fukushima MD
Objectif: Évaluer l'influence de la buprénorphine épidurale sur la concentration alvéolaire minimale (MAC) d'anesthésique volatil, la durée de l'anesthésie et la fonction respiratoire à la période périopératoire.

Méthodes: Cent vingt patientes de classe ASA I et II programmées pour une chirurgie gynécologique étaient réparties en trois études. Les 40 patientes de chaque études étaient divisées aléatoirement en quatre groupes déterminés selon la dose; Groupe I (contrôle), Groupe II (morphine $80 \mu \mathrm{g} \cdot \mathrm{kg}^{-1}$ ), Groupe III (buprénorphine $4 \mu \mathrm{g} \cdot \mathrm{kg}^{-1}$ ), Groupe $V$ (buprénorphine 8 $\mu \mathrm{g} \cdot \mathrm{kg}^{-\mathrm{I}}$ ). Le MAC de l'halothane était déterminé après l'administration épidurale de l'agent à l'étude dans chaque groupe. Le première demande de pentazocine permettait de préciser la durée de l'analgésie. La dose totale de pentazocine requise pendant les premières 48 h postchirurgicales évaluait les effets analgésiques postopératoires. À la période postopératoire, la fréquence respiratoire ( $F R$ ), le volume minute (VM) et la $\mathrm{PaCO}_{2}$ étaient notés. Le MAC de l'halothane diminuait dans le Groupe IV $(P<0,01)$. La durée de l'analgésie était de 10.0 $\pm 5,1 \mathrm{~h}$ (moyenne \pm ET) dans le Groupe $I$, de 37,7 $\pm 4,7 \mathrm{~h}$ dans le Groupe II, de 27,1 $\pm 7, h$ dans le Groupe III et de 44,4 $\pm 4,1$ h dans le Groupe IV. La dose totale de pentazocine était moins élevée dans le groupe $I V(P<0,05)$ que dans les autres groupes. Une baisse de $F R, M V$ et une augmentation de la $\mathrm{PaCO}_{2}$ proprotionnelles à la dose étaient observées en déçà de 60 min dans les groupes III et IV.

Conclusion: La buprénorphine épidurale administrée à des doses de 4 ou $8 \mu \mathrm{g} \cdot \mathrm{kg}^{-1}$ procure aune analgésie postopératoire aussi efficace que celle de la morphine.

Epidural administration of morphine has been used extensively since the initial positive report.' However, compared with the intrathecal route, epidural administration of opioids is complicated by pharmacokinetic aspects related to dural penetration, fat deposition, and systemic absorption. The effect of epidural opioids and analgesics on the onset and duration of analgesia is considered to be strongly correlated with its lipophilicity and hydrophilicity. ${ }^{2}$ The pharmacokinetic behaviour of the agents also influences the incidence of undesirable side effects, particularly early and late respiratory depression, which is often observed with epidural administration of morphine. ${ }^{3-5}$ 
Buprenorphine is a relatively new synthetic opioid with both agonistic and antagonistic properties. Unlike morphine, it is a more lipid soluble and less water soluble drug and is less likely to cause late respiratory depression. ${ }^{6}$

Systemic administration of opioids reduces the MAC of volantile anaesthetics, but there have been recent conflicting reports that intrathecal morphine does not reduce MAC, and the subject is still controversial.

This study was designed to evaluate the effects of epidural administration of morphine and buprenorphine, which have different hydro- and lipophilicy on the MAC of halothane, duration of analgesia, postoperative analgesic requirements and the respiratory function during and after surgery.

\section{Methods}

\section{Study population}

Following approval of the institutional ethical committee, 120 patients undergoing gynaecological surgery of the lower abdomen consented to participate in this study. All subjects were ASA I or II, and aged 25-62 yr. Subjects $>70$ yr or $>70 \mathrm{~kg}$ body weight were excluded. All patients underwent hysterectomy or ovarectomy for the removal of a benign tumour excluding laparoscopic surgery.

\section{Anaesthetic technique}

Premedication was administered with $0.5 \mathrm{mg}$ atropine sulphate im $30 \mathrm{~min}$ before induction of anaesthesia. After local anaesthesia, an epidural catheter was inserted at the interspace between $L_{3}$ and $L_{4}$ and advanced 3 $\mathrm{cm}$ cephalad into the epidural space. Morphine or buprenorphine with saline or lidocaine was injected via an epidural catheter according to the protocol. After confirming the level of analgesia by pin-prick $20 \mathrm{~min}$ after the injection, anaesthesia was induced with 5 $\mathrm{mg} \cdot \mathrm{kg}^{-1}$ thiopentone and tracheal intubation was facilitated with $1 \mathrm{mg} \cdot \mathrm{kg}^{-1}$ succinylcholine chloride iv $20 \mathrm{~min}$ before the incision.

\section{Study 1, MAC}

The patients were randomly divided into four groups of ten subjects .

Group I, $20 \mathrm{ml}$ saline via an epidural catheter;

Group II , $20 \mathrm{ml}$ saline and $80 \mu \mathrm{g} \cdot \mathrm{kg}^{-1}$ morphine via an epidural catheter;

Group III, $20 \mathrm{ml}$ saline and $4 \mu \mathrm{g} \cdot \mathrm{kg}^{-1}$ buprenorphine via an epidural catheter;

Group IV, $20 \mathrm{ml}$ saline and $8 \mu \mathrm{g} \cdot \mathrm{kg}^{-1}$ buprenorphine via an epidural catheter.

The patients breathed spontaneously throughout sur- gery with $6 \mathrm{~L} \cdot \mathrm{min}^{-1}$ oxygen. To determine MAC, the preselected end-tidal halothane concentration was maintained for a minimum of $20 \mathrm{~min}$ before the incision. A nerve stimulator was used to ensure no residual paralysis by succinylcholine chloride remained at the time of the incision. The presence or absence of movement was determined by a blinded observer. A positive response was defined as "gross purposeful" movement. ${ }^{7}$ If a patient did not move at incision, the next patient in the same treatment group was tested with a $0.1 \%$ lower halothane concentration. If movement was apparent, the halothane concentration was increased by $0.1 \%$. The MAC of halothane for each group was calculated and compared using logistic calculation. ${ }^{7}$

\section{Study 2, Postoperative analgesia}

The patients were divided randomly into four groups of ten subjects.

Group I, $20 \mathrm{ml}$ lidocaine $2 \%$ (control) via an epidural catheter;

Group II, $20 \mathrm{ml}$ lidocaine $2 \%$ and $80 \mu \mathrm{g} \cdot \mathrm{kg}^{-1}$ morphine via an epidural catheter;

Group III, $20 \mathrm{ml}$ lidocaine $2 \%$ and $4 \mu \mathrm{g} \cdot \mathrm{kg}^{-1}$ buprenorphine via an epidural catheter;

Group IV, $20 \mathrm{ml}$ lidocaine $2 \%$ and $8 \mu \mathrm{g} \cdot \mathrm{kg}^{-1}$ buprenorphine via an epidural catheter.

The patients' lungs were mechanically ventilated using pancronium bromide with a mixture of $\mathrm{N}_{2} \mathrm{O}$ (4 $\left.\mathrm{L} \cdot \mathrm{min}^{-1}\right)$ and $\mathrm{O}_{2}\left(2 \mathrm{~L} \cdot \mathrm{min}^{-1}\right)$ throughout surgery. In the postoperative period, when analgesia was requested, 15 mg pentazocine was injected $\mathrm{im}$. For further analgesia, the dose was repeated. The exact time and dose of pentazocine was recorded in the chart for $48 \mathrm{hr}$ after surgery. No other analgesics were administered during the postoperative period. The duration of analgesia was defined as the period from the epidural administration of the agents to the first request for analgesia. The effect of analgesia by epidural morphine or buprenorphine was assessed by the total dose of pentazocine required for 48 hr after surgery.

\section{Study 3, Respiratory function}

The patients were divided randomly into four groups of ten subjects in the same way as in study 2 . The patients breathed spontaneously throughout surgery with a mixture of $\mathrm{N}_{2} \mathrm{O}\left(4 \mathrm{~L} \cdot \mathrm{min}^{-1}\right)$ and $\mathrm{O}_{2}\left(2 \mathrm{~L} \cdot \mathrm{min}^{-1}\right)$. Respiratory rate (RR), Minute Volume (MV) and $\mathrm{PaCO}_{2}$ were measured continuously during surgery. The RR and MV were also measured at 6 and $12 \mathrm{hr}$ after the administration of morphine or buprenorphine.

Information regarding side effects such as nausea, vomiting, pruritus, and urinary retension was obtained 
from the chart in the recovery room. Any complaints of dyspnoea were also recorded every three hours.

Data were analyzed using unpaired Student $t$ test. $P<$ 0.05 was considered statistically significant. Data are presented as mean values \pm SD or SE.

\section{Results}

One hundred and twenty patients were investigated. Their mean age was $41.2 \pm 2.6 \mathrm{yr}$ (mean $\pm S D$ ), and body weight was $59.9 \pm 9.8 \mathrm{~kg}$ (mean $\pm \mathrm{SD})$. The duration of surgery was $118 \pm 29$ min. (mean $\pm S D$ ).

\section{Study 1}

\section{MAC OF HALOTHANE}

The MAC of halothane was $0.79 \pm 0.03 \%$ (mean \pm SE) in Group I, $0.62 \pm 0.03 \%$ in Group II, $0.61 \pm 0.02 \%$ in Group III, and $0.40 \pm 0.02 \%$ in Group IV. The MAC of halothane in Group IV was lower than that in the others. $(P<0.01)$ (Figure 1).

\section{Study 2}

\section{DURATION OF ANALGESIA}

The time from the epidural administration of the agents until the first request for pentazocine for postoperative pain relief was $10.0 \pm 5.1 \mathrm{hr}$ (mean $\pm \mathrm{SE}$ ) in Group I, $37.7 \pm 4.7 \mathrm{hr}$ in Group II, 27.1 $\pm 7.1 \mathrm{hr}$ in Group III, and $44.4 \pm 4.1 \mathrm{hr}$ in Group IV. The duration of analgesia in Groups II, III and IV was longer than that of Group I ( $P$ $<0.05$ ). There were no differences between Group II, III, and IV (Figure 2).

\section{POSTOPERATIVE ANALGESIA}

The total dose of pentazocine during the $48 \mathrm{hr}$ after surgery in Group I was $15.0 \pm 6 \mathrm{mg}$ (mean $\pm \mathrm{SE}$ ), $6.7 \pm$ $4 \mathrm{mg}$ in Group II, $6.0 \pm 3 \mathrm{mg}$ in Group III, and $2.5 \pm 2$ $\mathrm{mg}$ in Group IV. The dose in Group IV was lower than that of the other groups. $(P<0.05)$ (Figure 3 ).

\section{Study 3}

\section{RESPIRATORY RATE (RR)}

Sixty minutes after the administration of morphine or buprenorphine, RR remained within the normal range (15 to $20 \cdot \mathrm{min}^{-1}$ ) in Group I. Compared with Group I, RR decreased by $15 \%$ in Groups II and III, and decreased by approximately $50 \% 60 \mathrm{~min}$ after the administration of $8 \mu \mathrm{g} \cdot \mathrm{kg}^{-1}$ buprenorphine in Group IV $(P<0.05)$ (Figure 4).

\section{MINUTE VOLUME (MV)}

Sixty minutes after the administration of morphine or

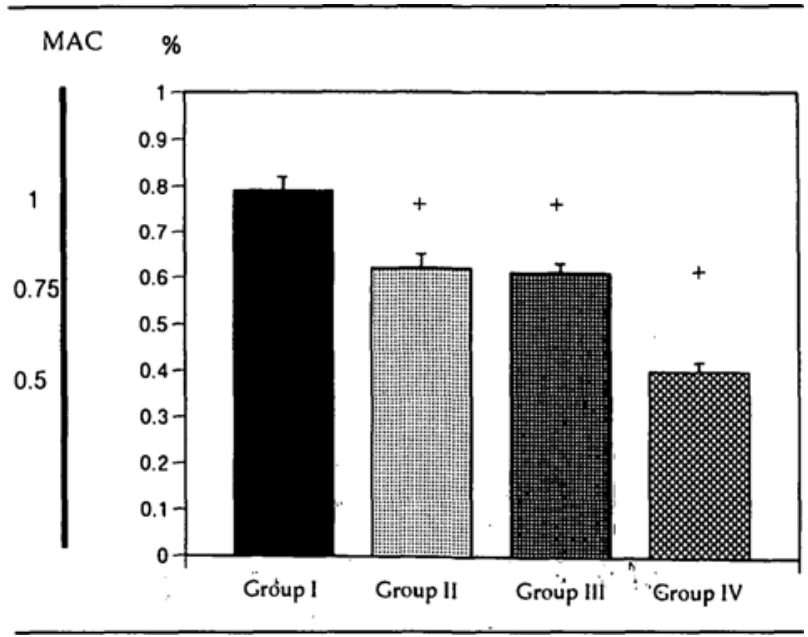

FIGURE 1 Change of the minimum alveolar concentration (MAC) of halothane. MAC of halothane decreased in Group IV compared with Group I $(P<0.01)$.

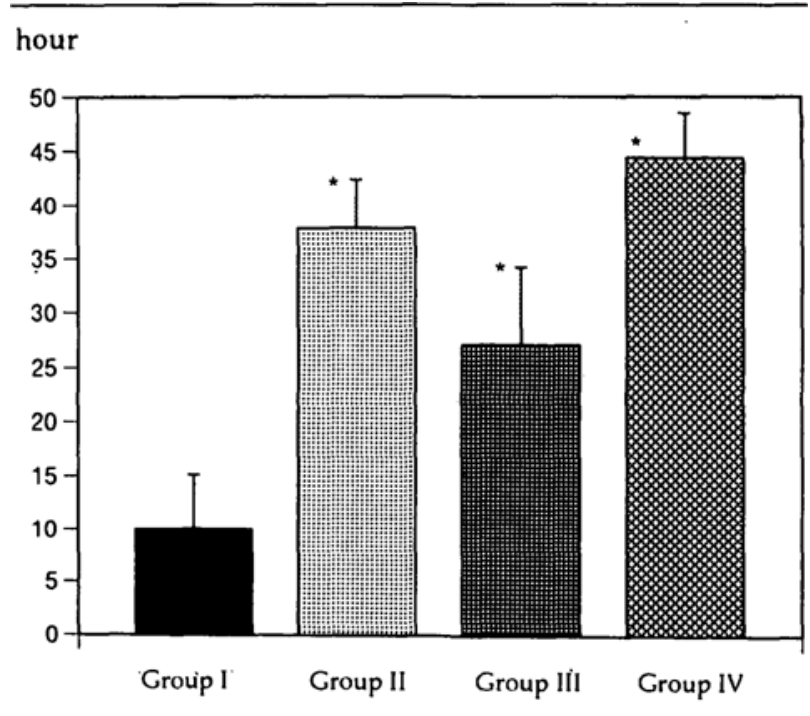

FIGURE 2 Duration of analgesia. The duration of analgesia in Group II , Group III, and Group IV was longer than that in Group I $(P<0.05)$

buprenorphine, $\mathrm{MV}$ decreased to $3.8 \pm 0.41 \mathrm{~L} \cdot \mathrm{min}^{-1}$ (mean \pm SE) in Group II and $4.1 \pm 0.88 \mathrm{~L} \cdot \mathrm{min}^{-1}$ in Group III. In Group IV, MV decreased sharply to $3.4 \pm$ $0.61 \mathrm{~L} \cdot \mathrm{min}^{-1} 30 \mathrm{~min}$ after the administration $(P<0.01$, compared with Group I) and $3.6 \pm 0.85 \mathrm{~L} \cdot \mathrm{min}^{-1} 60 \mathrm{~min}$ after the administration (Figure 5).

$\mathrm{PaCO}_{2}$

The mean value of $\mathrm{PaCO}_{2}$ in Group I was $39.5 \pm 1.7$ mmHg. (mean $\pm \mathrm{SE}$ ). The $\mathrm{PaCO}_{2}$ in Group IV at $60 \mathrm{~min}$ was $47.0 \pm 1.4 \mathrm{mmHg}$ which was higher than that of 


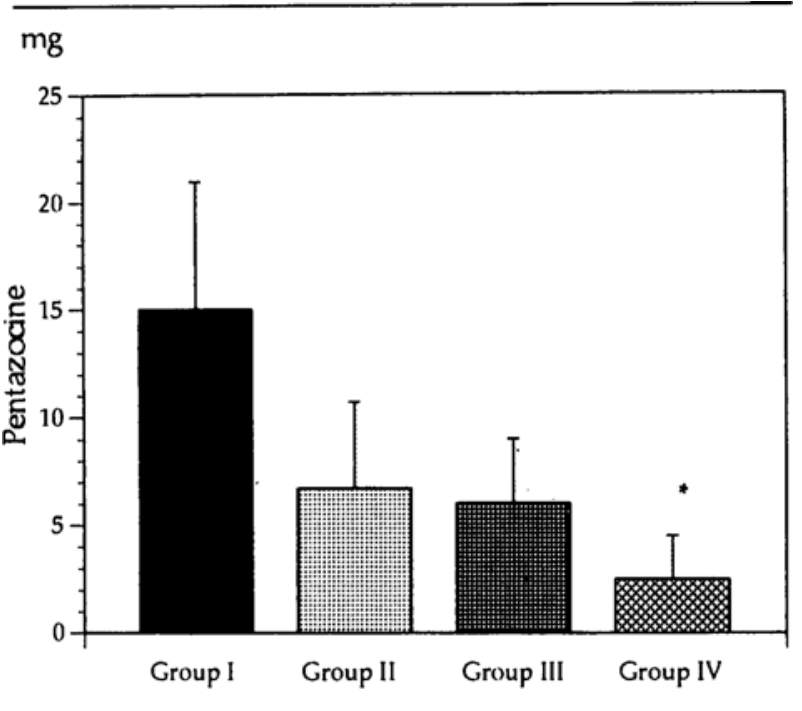

FIGURE 3 Postoperative analgesia. The total dose of pentazocine $48 \mathrm{hr}$ after surgery in Group IV was less than that in the other groups $(P<0.05)$

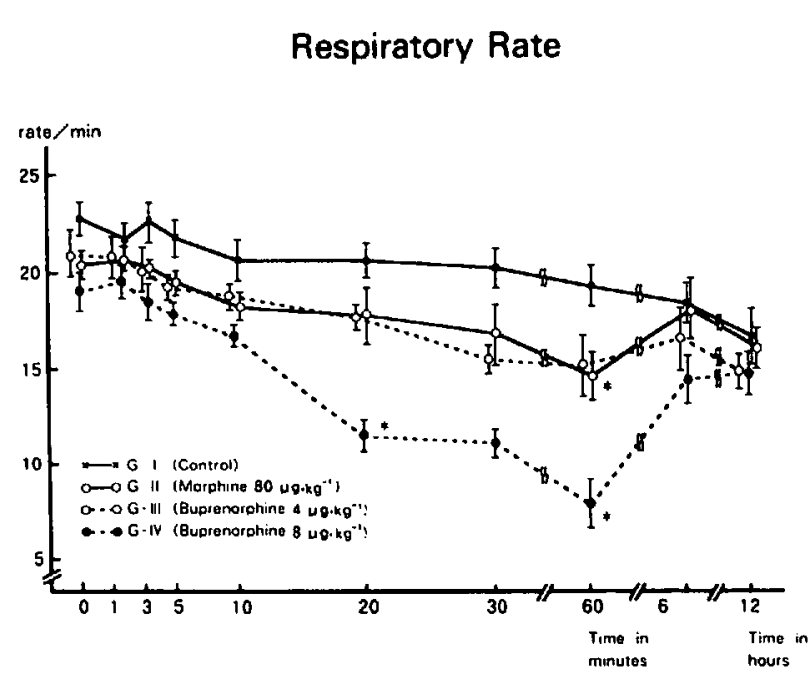

FIGURE 4 Change of the respiratory rate. Sixty minutes after the administration of morphine or buprenorphine, the respiratory rate (RR) decreased by $15 \%$ in Group II and Group III, 50\% in Group IV ( . - $(P<0.05)$ compared with Group I.

Group I $(P<0.05)$. There were no changes in $\mathrm{PaCO}_{2}$ in Group I, II, and III (Figure 6).

\section{Side effects}

There were no serious side effects requiring treatment in any patient. No undesirable side effects such as pruritus,or urinary retention were observed except in two patients in Group II who experienced nausea. There was

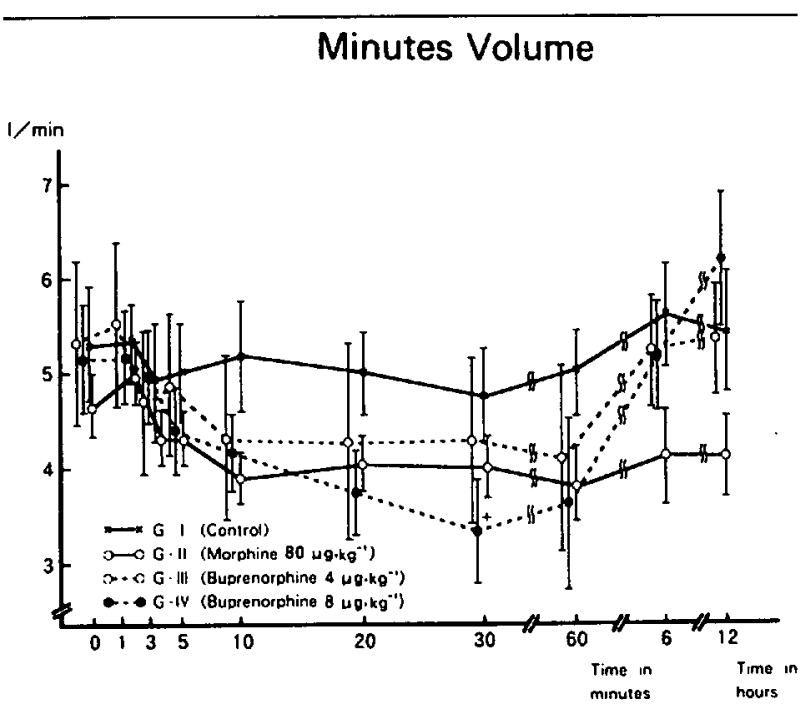

FIGURE 5 Change of the minute volume (MV). The MV decreased in Group II , Group III and Group IV $60 \mathrm{~min}$ after the administration of morphine (O - O O). In Group IV ( - - ) , MV had decreased 30 min after the administration of buprenorphine $(P<0.01)$.

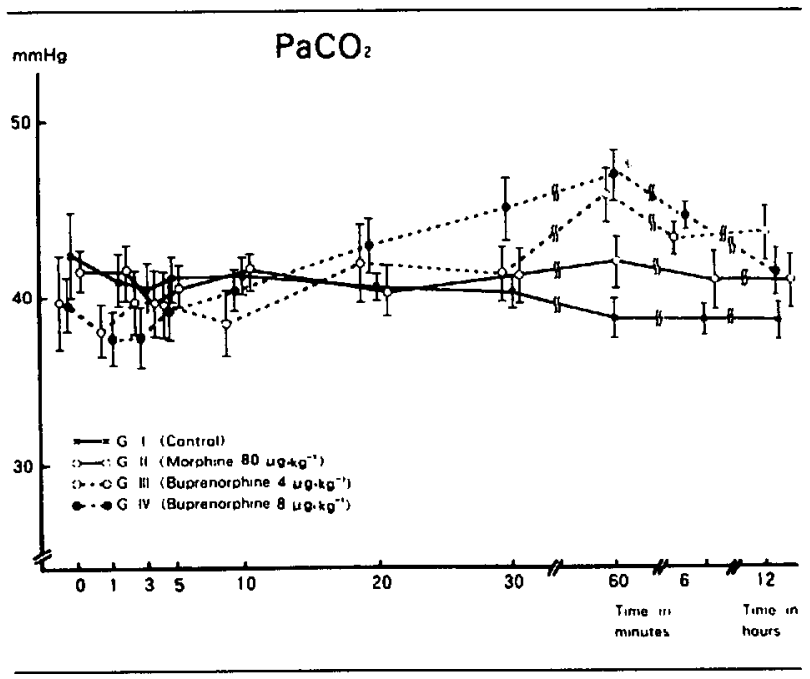

FIGURE 6 Change of $\mathrm{PaCO}_{2}$. The $\mathrm{PaCO}_{2}$ in Group IV( - - $\bullet$ had increased $60 \mathrm{~min}$ after the administration of buprenorphine $(P<0.05$, compared with Group I).

no correlation between dose and side effects in epidural administration of buprenorphine in Groups III or IV.

\section{Discussion}

The transmission of pain is not a simple passive process but is produced by messages between neuronal systems at many levels of the central nervous system which converge on the spinal cord. ${ }^{8.9}$ It is well known that wind-up and NMDA receptor activation can be induced with electrical, mechanical, and inflammatory $\mathrm{C}$-fibre 
stimulation. These events are likely to occur during surgical procedures even in the presence of anaesthesia. ${ }^{10}$

Recent work has revealed that pre-emptive analgesia is relevant for postoperative pain relief by suppressing hypersensitivity of neurons and blocking abnormal exaggerated pathways. ${ }^{10-12}$ Opioids and local anaesthetics exert their antinociceptive effects in the spinal cord by a different mechanism and opioids prolong the duration of local anaesthetic-induced sensory blockade. A combination of these agents may offer a theoretical advantage for postoperative pain relief. ${ }^{13}$

Postoperative analgesia by epidural opioids has been tested in numerous studies and is now widely used in clinical practice. Although morphine has been the most commonly used opioid, it can cause side effects such as: pruritus, nausea, vomiting, urinary retention, and respiratory depression. ${ }^{14-16}$

Buprenorphine is a relatively new synthetic opioid with both agonist and antagonist properties, and has a high receptor affinity and lipid solubility ${ }^{6}$ with less physical dependence. ${ }^{17}$ Unlike morphine, the more lipid soluble and less water soluble drugs, such as buprenorphine and fentanyl are less likely to cause late respiratory depression unless an extremely large dose is used. It may be preferable to morphine when used perioperatively as a pre-emptive agent.

Systemic administration of opioids reduces the MAC of volatile anaesthetics by 20 to $60 \%$ in animals and humans, depending on the dosage and route of administration. ${ }^{18-22}$ However, a conflicting report has recently emerged suggesting that intrathecal morphine does not reduce $\mathrm{MAC}^{23}$

In our study, the MAC of halothane in the control group corresponded to previously published values, ${ }^{24}$ while epidural administration of morphine reduced the MAC of halothane by $22 \%$, and buprenorphine reduced it by $23 \%$ after administration of $4 \mu \mathrm{g} \cdot \mathrm{kg}^{-1}$ and $49 \%$ after $8 \mu \mathrm{g} \cdot \mathrm{kg}^{-1}$ respectively. This reduction probably resulted from impairment of rostral transmission of nociceptive impulses by binding of spinal opioid receptors as well as activation of supraspinal opioid sensitive sites. Opioids produced analgesic effects both during and after surgery, and the analgesic effect of buprenorphine was dose-dependent.

Early and late respiratory depression is a major complication when opioids are administered into the intrathecal or epidural space. In our study, eàrly respiratory depression occurred within $60 \mathrm{~min}$, indicated by the decrease of RR and $\mathrm{MV}$, and increase of $\mathrm{PaCO}_{2}$, after epidural buprenorphine. Respiratory depression was most remarkable in the patients of Group IV $\left(8 \mu \mathrm{g} \cdot \mathrm{kg}^{-1}\right.$ buprenorphine) but they recovered without treatment. This early respiratory depression probably reflects the absorption via epidural veins and rapid distribution to the brain as suggested by Cousin et al. ${ }^{25}$ and it may be explained by its lipophilicity which also induces the rapid onset and medium duration of analgesia of epidural buprenorphine. Compared with morphine, which tends to linger in the water phase in the cerebrospinal fluid (CSF) and spread more widely and rostrally ${ }^{26}$ in the spinal canal due to its hydrophylicity, buprenorphine can reach the brain more quickly due to the rapid uptake into the epidural veins, as Moore et al. suggested. ${ }^{27}$ The high lipophilicity and relatively small molecular weight of buprenorphine lead to rapid vascular removal. Late respiratory depression was not recorded in the $48 \mathrm{hr}$ after surgery in any group, probably because epidural administration of morphine $80 \mu \mathrm{g} \cdot \mathrm{kg}^{-1}$ was not a large enough dose to cause late respiratory depression in relatively healthy middle-aged patients.

Postoperative analgesia was obtained in both groups receiving epidural morphine and buprenorphine. Duration of analgesia, evaluated by the first request for pentazocine after surgery, was longer in both groups of buprenorphine and morphine than in the control group, and was dependent on the dose of buprenorphine. The effect of morphine $80 \mu \mathrm{g} \cdot \mathrm{kg}^{-1}$ on the duration of analgesia was similar to that of buprenorphine $8 \mu \mathrm{g} \cdot \mathrm{kg}^{-1}$. The total dose of pentazocine during the $48 \mathrm{hr}$ after surgery was lower in the group receiving buprenorphine $8 \mu \mathrm{g} \cdot \mathrm{kg}^{-1}$ than in the control group. Thus, the epidural administration of opioids caused prolonged analgesia when used as a supplement to local anesthesia. There was no difference between morphine and buprenorphine in our study although the effectiveness of buprenorphine could have been dose-dependent.

The ideal dose of buprenorphine to add to the intrathecal space suggested by Valenti was $3 \mu \mathrm{g} \cdot \mathrm{kg}^{-1}$, which produced the same duration of analgesia as 7 $\mu \mathrm{g} \cdot \mathrm{kg}^{-1}$ of morphine, but with fewer side effects. ${ }^{28}$ Raudomanska et al. showed that epidural administration of $0.3 \mathrm{mg}$ buprenorphine was safe and effective for postoperative pain relief. ${ }^{29}$ In contrast, Wolff reported that $0.3 \mathrm{mg}$ buprenorphine administered epidurally provided similar analgesia to $4 \mathrm{mg}$ morphine, and did not offer any advantages over morphine following orthopaedic surgery. However a high incidence of pruritus and urinary retention was reported with the administration of morphine..$^{30}$

We studied two different doses of buprenorphine, 4 and $8 \mu \mathrm{g} \cdot \mathrm{kg}^{-1}$. Increasing the dose of buprenorphine did extend the duration of analgesia but increased the respiratory depression within $60 \mathrm{~min}$ in the case of the 8 $\mu \mathrm{g} \cdot \mathrm{kg}^{-1}$ buprenorphine although this recovered without treatment. In our investigation no high risk patients were studied and no serious side effects occurred following 
gynaecological surgery. Therefore the "risk profile" must be taken into account when deciding on dose.

It is uncertain whether epidural buprenorphine offers any benefits compared with morphine, because the effectiveness of analgesia and incidence of complications may depend on the dose, the patient's physical and mental condition, and the type of surgery. However epidural administration of buprenorphine has the possibility of being used widely in clinical practice in the same way as morphine to prolong the duration of analgesia, and produce less undesirable side effects such as late respiratory depression due to its high lipid solubility.

In conclusion, epidural buprenorphine administration of 4 or $8 \mu \mathrm{g} \cdot \mathrm{kg}^{-1}$ provided prolonged analgesia when used as a pre-emptive analgesia and resulted in dosedependent reductions of anaesthesia during surgery and analgesics in the postoperative period.

\section{References}

1 Behar M, Magora F, Olshwang D, Davidson JT. Epidural morphine in treatment of pain. Lancet 1979; 1: 5.27-9 .

2 Bromage PR. The price of intraspinal narcotic analgesia: basic constraints (Editorial). Anesth Analg1981;60: 461-3.

3 Davis GK, Tolhurst-Cleaver CL, James TL. CNS depression from intrathecal morphine (Letter). Anesthesiology 1980; 52: 280 .

4 Davis GK, Tolhurst-Cleaver CL, James TL. Respiratory depression after intrathecal narcotics. Anaesthesia 1980; 35: 1080-3.

5 Christensen V. Respiratory depression after extradural morphine (Letter). Br J Anaesth 1980; 52: 841 .

6 Hambrook $J M$, Rance $M J$. The interaction of buprenorphine with the opiate receptor: lipophilicity as a determining factor in drug-receptor kinetics. In: Kosterilitz HW (Ed.). Opiates and Endogenous Opioid Peptides.

Amesterdam: Elsevier/North-Holland Biomedical Press, 1976: 295-301.

7 Merkel G, Eger EI II. A comparative study of halothane and halopropane anesthesia. Anesthesiology 1963; 24: 346-57.

8 Schouenborg $J$, Sjolund BH. Activity evoked by A- and $\mathrm{C}$-afferent fibers in rat dorsal horn neurons and its relation to a flexion reflex. J Neurophysiol 1983; 50: 1108-21.

9 Shouenborg J, Dickenson A. Long-lasting neuronal activity in rat dorsal horn evoked by impulses in cutaneous $\mathrm{C}$ fibres during noxious mechanical stimulation. Brain Res 1988; 439: 56-63.

10 Dickenson $A H$. Recent advances in the physiology and pharmacology of pain: plasticity and its implications for clinical analgesia. Journal of Psychopharmacology 1991; 5: 342-51.
11 Dickenson $A H$, Sullivan $A F$. Electrophsiological studies on the effects of intrathecal morphine on nociceptive neurones in the rat dorsal horn. Pain 1986; 24: 211-22.

12 Woolf $C J$, Chong $M$-S. Preemptive analgesia - treating postoperative pain by preventing the establishment of central sensitization. Anesth Analg 1993; 77: 362-79.

13 Singh $H$, Yang J, Thornton $K$, Giesecke $A H$. Intrathecal fentanyl prolongs sensory bupivacaine spinal block. Can J Anaesth 1995; 42: 987-91.

14 Bromage PR, Camporesi E, Chestnut D. Epidural narcotics for postoperative analgesia. Anesth Analg 1980; 59: 473-80.

15 Gustafsson LL, Schildt B, Jacobsen $K$. Adverse effects of extradural and intrathecal opiates: report of a nationwide survey in Sweden. Br J Anaesth 1982; 54: 479-86.

16 Fukushima K, Nakamura M, Ishikawa J, Nagashima $H$, Fordes FF. CSF morphine concentration and analgesic effect. Jap J Anaesth 1984; 33: 110-4 .

17 Lewis JW. Ring C-bridged derivatives of thebaine and oripavine. Narcotic antagonists. In: Braude MC, Harris LS, May EL, Smith JP, Villarreal JE (Eds.). Advances in Biochemical Psychopharmacology, Vol 8. New York: Raven Press, 1974: 123-36.

18 Murphy MR, Hug CC Jr. The enflurane sparing effect of morphine, butorphanol, and nalbuphine. Anesthesiology. 1982; 57: 489-92.

19 Saidman LJ, Eger EI II. Effect of nitrous oxide and narcotic premedication on the alveolar concentration of halothane required for anesthesia. Anesthesiology 1964; 25: 302-6.

20 Schwieger IM, Szlam F, Hug CC Jr. Absence of agonistic or antagonistic effect of flumazenil (Ro-15-1788) in dogs anesthetized with enflurane, isoflurane, or fentanyl-enflurane. Anesthesiology 1989; 70: 477-80.

21 Schwieger IM, Klopfenstein CE, Forster A, Epidural morphine reduces halothane MAC in humans. Can J Anaesth 1992; 39: 911-4.

22 Valverde A, Dyson DH, McDonell WN. Epidural morphine reduces halothane MAC in the dog. Can J Anaesth 1989; 36: 629-32.

23 Licina MG, Schubert A, Tobin JE, et al. Intrathecal morphine does not reduce minimum alveolar concentration of halothane in humans: results of a double-blind study. Anesthesiology 1991; 74: 660-3.

24 Gregory GA, Eger EI II, Munson ES. The relationship between age and halothane requirement in man. Anesthesiology 1969; 30: 488-91.

25 Cousins MJ, Mather LE. Intrathecal and epidural administration of opioids. Anesthesiology 1984; 61: 276-310.

26 Bromage PR, Camporesi EM, Durant PAC, Nielsen CH. Rostal spread of epidural morphine. Anesthesiology 1982; 56: 431-6.

27 Moore RA, Bullingham RES, McQuay HJ, et al. Dural 
permeability to narcotics: in vitro determination and application to extradural administration. Br J Anaesth 1982; 54 : 1117-28.

28 Valenti S, Seggato A, De Bianchi E, Vincenti E, Giron GP. Buprenorphine vs morphine both spinally injected and postoperative pain relief. Pain 1987; 4: S73.

29 Rondomanska $M$, de Castro J, Lecron $L$. The use of epidural buprenorphine for the treatment of postoperative pain. In: Yaksh T, Muller H (Eds.). Spinal Opiate Analgesia. Experimental and Clinical Studies. Anesthesiology and Intensive Care Medicine. Springer Verlag, 1982; 144: 91-4.

30 Wolff J, Carl P, Crawford ME. Epidural buprenorphine for postoperative analgesia. A controlled comparison with epidural morphine. Anaesthesia1986; 41: 77-9. 